\title{
FEEDING OF SPORTING DOGS PART I. ENERGY, PROTEIN, FAT AND CARBOHYDRATES REQUIREMENTS
}

Department of Monogastric Animal Sciences, Division of Animal Nutrition and Food, West Pomeranian University of Technology in Szczecin, Poland

\begin{abstract}
Sporting dogs belong to a large group of dogs that perform a specific job for a man. The type of performed work can be divided according to its frequency, intensity and duration. The aim of the study was to characterize the nutrition of sporting dogs, focusing on energy requirement and demand for energy-providing nutrients (protein, fat and carbohydrates). Proper nutrition is one of the most important factors affecting the dog's athletic performance. The objective of proper nutrition for training dogs is to provide the highest quality of energy in appropriate amount. Food balance is achieved when the supplied nutrients enable the body to maintain the proper functioning of all tissues and none of the ingredients are in excess or deficiency.
\end{abstract}

Key words: working dogs, diet, nutritional requirements.

\section{INTRODUCTION}

The domestic dog (Canis lupus f. familiaris) has the greatest diversity among all mammal species. Depending on the breed, differences in the size of adult dogs reach a span of up to $100 \mathrm{~kg}$, starting from miniature dog breeds (from $1 \mathrm{~kg}$ ) to giant dog breeds (up to $100 \mathrm{~kg}$ ) (Drake and Klingenberg, 2010). These differences can also affect the way the dog is used in everyday life. Many breeds are classified as working breeds, exposed to appropriate training and work tests. There are, among others: hunting dogs, guard dogs, police dogs, herding dogs, rescue dogs, therapy dogs, and dog athletes (Fernandes et al. 2017; Horoszewicz et al. 2018).

Sporting dogs belong to a large group of dogs that perform a specific job for a man. The various tasks performed by the command of dog owners are associated with physical activity and mental activity as well. The type of performed work can be divided according to its frequency, intensity and duration (Wakshlag and Shmalberg 2014). The most important factor in the adaptation of a dog for sports and work appears to be a genetic factor (Turcsán et al. 2011). It determines the possibility of the dog, or rather its structural and metabolic limitations. However, both training and nutrition properly selected, allow maximum use of the genetic potential. Therefore, regardless of the sport discipline and regardless of the breed, the dog can achieve its full sports potential with precisely selected diet and proper training.

Corresponding author: Katarzyna Kazimierska, Department of Monogastric Animal Sciences, Division of Animal Nutrition and Food, West Pomeranian University of Technology in Szczecin, 29 Klemensa Janickiego, 71-270 Szczecin, Poland, e-mail: katarzyna.kazimierska@zut.edu.pl 
Therefore, the owner of a sporting dog should be aware that proper nutrition is one of the most important factors influencing the sporting performance of the dog. Every day, a sporting dog faces various psychophysical loads that affect food requirement. Sporting animals require a special feeding method that is suitable for the body spending a lot of energy during exercise. Similarly to humans, the demand for individual nutrients is increased due to increased physical effort (Wakshlag and Shmalberg 2014). Increased metabolism rises nutritional needs. In addition to optimal nutritional composition, food should be administered in the right amount for each dog, and the frequency should be adapted to the training plan or working time. The objective of proper nutrition for training dogs is to provide the highest quality of energy in sufficient quantity. Food balance is achieved when the nutrients supplied allow the body to maintain the proper functioning of all tissues and none of the ingredients are in excess or deficiency.

The aim of the study was to characterize the nutrition of sporting dogs, focusing on energy requirement and demand for energy-providing nutrients (protein, fat and carbohydrates).

\section{ENERGY REQUIREMENT}

The energy requirement is a fundamental element conditioning the sporting dog's diet. Due to increased physical and mental activity, usually, the amount of calories in the diet of the sporting dog is higher than in the adult dog with normal activity. The daily energy requirement depends primarily on the dog's body weight, stage of life, physiological state, health and level of physical activity. In turn, the extent to which the activity of the dog will increase the calories requirement depends on three factors: the intensity, duration, and frequency of exercise.

Short-term, but intense physical effort requires a lot of energy expended in a relatively short time (<2 min). This type of effort mainly characterizes dog sprint races, greyhound races, flyball competitions, and overcoming the agility track in a very short time. The energy required for work is derived from the chemical transformations of phosphocreatine, which occur with the participation of the enzyme - creatine kinase. The amount of produced adenosine-5'triphosphate (ATP) is enough for about 1-2 seconds of muscle work. Then the body reaches the accumulated reserves, muscle glycogen, from which, depending on the pathway (anaerobic/aerobic), 2 or more ATP molecule are formed. Because glycogen reserves are limited (1-2\%), during the next minutes of muscle work, fatty acid oxidation mechanisms are activated - providing energy for the next 2-3 hours of work. In case of the absence of sufficient energy to work, the body reaches the amino acid reserves and as a result of burning endogenous proteins, an unfavorable catabolism process is initiated. It is worth noting that depending on the intensity of the dog's work, the energy required by the body will come from different sources. During short-term and intensive muscle work, the body uses glucose, while in intermediate work glucose and fats, and during low-intensity endurance work mainly uses fats (Wakshlag and Shmalberg 2014).

According to Case (2014), cynological sports can be classified into their duration, intensity, and their impact on energy demand (Table 1). In addition to these factors, the daily energy requirement (DER) working dog may undergo certain modifications due to factors such as e.g.: 
the stress caused by competition or the presence of other dogs and people, ambient temperature, type of terrain and the substrate (Loftus et al. 2014 ). Furthermore, the dogs in all weather conditions have to maintain a constant body temperature, which in the case of high temperatures consists in giving off heat (mainly by exfoliation), and at low temperatures on heat generation (tremor thermogenesis, non-tremor, postprandial). The energy requirement is increasing at low temperatures. If the dog is working in winter, energy intake must also take into account the environmental conditions such as temperature (Kronfeld et al. 1994). This primarily concerns sled dogs training at extremely low temperatures (Table 2).

Table 1. Examples of canine sports: the duration and intensity of exercise and caloric requirement

\begin{tabular}{lccc}
\hline \multicolumn{1}{c}{ Type of activity } & Intensity & Duration & Energy requirement \\
\hline Sled dogs, long distance running & moderate & long & very high \\
Hunting dogs & low & long & high \\
Recreational running & moderate & short to medium & moderate \\
Flyball & moderate to high & short & moderate \\
Agility & moderate to high & short & low to moderate \\
Coursing & very high & short & low \\
\hline
\end{tabular}

Table 2. Recommendations for daily energy requirement (DER) for dogs in relation to activity

\begin{tabular}{lcc}
\hline Activity level & $\mathrm{kcal}\left(\mathrm{kg}^{0.75}\right)^{-1}$ & $\mathrm{~kJ}^{\left(\mathrm{kg}^{0.75}\right)^{-1}}$ \\
\hline Low activity (<1h/day) (e.g. walking on the lead) & 95 & 398 \\
Moderate activity (1-3 h/day) (low impact activity) & 110 & 460 \\
Moderate activity (1-3 h/day) (high impact activity) & 125 & 523 \\
High activity (3-6 h/day) (working dogs, e.g. sheep dogs) & $150-175$ & $3600-5190$ \\
High activity under extreme conditions (racing sled dogs 168 km/d & $860-1240$ & $3600-5190$ \\
in extreme cold) & & \\
\hline
\end{tabular}

Source: FEDIAF(2019).

It should also be remembered that the diet of a sporting dog in the periods between competitions, with moderate physical exertion, does not differ from living needs. In addition to the proper quantitative and qualitative selection of the ingredients in the athlete's diet, the digestibility of nutrients is also very important. High digestibility allows the optimal use of nutrients with minimal production of undigested debris. Moreover, high digestibility also decreases energy wastes that the body incurs in digestion and absorption and therefore obtains the maximum amount of energy with the possibility of spending on work.

\section{PROTEIN}

Physical exercise stimulates catabolic processes in the body. Regular and prolonged exercise can cause a reduction in the level of albumin and blood serum. During exercise, their level decreases further. Furthermore, intensive exercise causes damage to muscle fibers, which leads to increased creatine kinase activity in blood serum (McKenzie et al. 2007; Tvarijonaviciute et al. 2017; Jahr et al. 2019). Therefore, an adequate supply of high-value protein should always be taken into account when a diet for a sporting dog is composed. 
The amount of protein provided with food must compensate for losses and provide substrates for building new proteins. Therefore, dietary protein has mainly building functions, and to a much lesser extent, it acts as a source of energy. It has some energetic significance during runs lasting longer than 30 minutes (Hill 2004). Since sled dogs subjected to long-term efforts have a high demand for protein. Insufficient supply of this component in the sled dog diet can lead to anemia (Kronfeld et al. 1977; Adkins and Kronfeld 1982). Therefore, at least $30 \%$ of the energy in the feed ration for sled dogs should come from protein (Adkins and Kronfeld 1982). In the study of Pratt-Phillips et al. (2018) the effect of increased protein intake in sled dogs on the dog's water balance was examined. After exercise testing, control dogs had higher serum urea nitrogen levels than dogs receiving low-protein foods, and albumin content were further reduced during the 5-day exercise test. Furthermore, the dogs fed food with low protein content have a lower amount of total body water and higher $\mathrm{Na}^{+}$excretion. It was found that reduced protein intake does not adversely affect athletic performance.

However, not only the protein content of the diet is essential, but also its amino acid composition, which is why the type of protein supplied is also important. The best source of high-quality protein for dogs is meat (Mirowski 2011). Plant proteins have a lower nutritional value because they are deficient in some essential amino acids. Exercise imposes additional requirements on the animal's body, and dogs fed a meatless diet may be at increased risk of sports anemia. However, Brown et al. (2009) showed that a carefully balanced plant diet can maintain normal hematological values in exercising dogs, without the risk of anemia caused by exercise. It is worth mentioning that this was the experimental diet consisting of corn gluten, corn grain, soy flour, rice, vegetables, vitamins, minerals, and sodium caseinate. Deficiency of animal-derived proteins in the diet of sporting dogs may, however, negatively affect the hematological parameters (reduction of hemoglobin content and the number of erythrocytes in the blood) and the course of numerous processes, especially those related to muscle tissue metabolism (Helman et al. 2003). In addition to valuable exogenous amino acids in the dog's diet, the meat also provides many other nutrients important for the dog's body undergoing physical exertion, among others glutamine, carnosine, coenzyme Q10 or creatine (Harris et al. 1997; Murray et al. 1997; Donadelli et al. 2019).

Appropriate amino acid supplementation, e.g. the addition of tryptophan in the diet, can reduce the incidence of exercise-induced disorders. Templeman et al. (2020) demonstrated that the optimization of the ratio of tryptophan to the content of the remaining amino acids in the diet can help to improve the health of the gastrointestinal tract without sacrificing performance in the active sled dog training.

In the nutrition of a sporting dog, the relative proportion of nutrients is as important as the amount of individual nutrients. The optimal protein level in the diet of sporting dogs is $30 \%$ metabolic energy (ME) with a fat content of $60 \%$ ME (Hill 1998). The proportions of protein to carbohydrate content in the diet are also important. In the sporting dog nutrition carbohydrates should be combined with the protein, to intensify the increase in glycogen content in skeletal muscle (Biel et al. 2017). It has been proven that an increase in the amount of protein in food for sporting dogs at the expense of carbohydrate content affects the deterioration of results 
achieved by dogs. Greyhounds receiving the feed in which the protein constituted $37 \%$ and the carbohydrates constituted $30 \% \mathrm{ME}$, covered the distance 500 meters by 0.18 seconds slower than the dogs fed the food in which the protein constituted $24 \%$ and the carbohydrates 43\% ME (Hill et al. 2001).

\section{FAT}

Fat has more than twice energy content than carbohydrates. It determines the taste of food and it is willingly eaten by dogs. Most animal fats contain saturated fatty acids, which during combustion generate less free radicals than unsaturated fatty acids of plant origin. Animal fats are the only source of essential unsaturated eicosapentaenoic acid (EPA) and docosahexaenoic acid (DHA). Fish oil and krill oil in particular are rich in them (Ramprasath et al. 2013). These acids, among other advantages, protect the dog against arthritis, but above all, which is important for the athlete, they increase resistance to oxidative stress, and at the same time improve exercise capacity, slow down aging processes and reduce the incidence of pathological changes in sporting dogs and reduce inflammation (Wakshlag and Shmalberg 2014; Głogowski and Hołda 2017).

The requirement for fat in the diet of the sporting dog is different depending on the activity. For dog sprinters, the amount of fat in the dry matter of food should be approximately $8 \%$, while sled dogs can receive $40 \%$ or more of lipids in dry matter (Barrette 1989). In feeding racing greyhounds, excessive fat supply should be avoided. It has been shown that charts receiving a diet in which the ME $75 \%$ was from fat, run slower than charts fed a diet containing $31 \%$ fat ME (Toll et al. 1992). Dog sprinter must be light and versatile, so providing this group of dogs the amount of fat, whereby the risk is minimized to its excessive accumulation in the body, seems to be necessary.

In turn, sled dogs over long distances are fed diets high in fat since lipid metabolism has long been considered as the major substrate used during endurance racing. Prolonged effort causes a significant increase in the dog's energy requirements. This is compounded by the severe weather, in which competitions often take place. High energy demands require increased energy concentration in the food ration. This may reduce the risk of loss of body weight and avoid feeding too much food and overburdening the gastrointestinal tract (Mirowski 2016). In sled dogs, fat is the main energy component that can provide up to $60 \%$ of energy (Reynolds et al. 1994). However, research by Gamble et al. (2018) suggested that sled dogs are equally, if not more, dependent on carbohydrate metabolism. This is confirmed by Loftus et al. (2014), in which it was observed that the carbohydrate content of the analyzed sled dog diets suggests that the presumed fat intake for endurance dogs may be slightly lower than previously thought.

\section{CARBOHYDRATES}

Dog sprinters derive energy primarily from accumulated in the muscles ATP, phosphocreatine, and glucose. Therefore, when creating a diet for this group of dogs, special attention should be paid to a sufficiently high supply of carbohydrates. However, on the other 
hand, the number of carbohydrates cannot be excessive. It has been proven (Hill et al. 2000) that racing greyhounds run faster when they are fed on a diet containing more fat and protein and lower carbohydrate content. Therefore, it can be assumed that the most appropriate amount of carbohydrates in the diet of sporting dogs working short, but intensively, should be from 30\% to 50\% ME (i.e. 75-125 g $1000 \mathrm{kcal}^{-1}$ ) (Wakshlag and Shmalberg 2014).

Dietary fiber classified as complex carbohydrates is not an exogenous ingredient for dogs, but it has a positive effect on the functioning of the digestive tract and the health of the whole body (Diez et al. 1998). It was found that the addition of carbohydrates to the diet after exercise has a positive effect on the work and regeneration of the dog's body. In a study conducted on 12 weight pulling dogs (Kim et al. 2019) have shown that carbohydrate and protein supplementation after exercise supports glucose metabolism and changes fatty acid metabolism. Reynolds et al. (1997) showed that providing sled dogs immediately after the run easily digestible glucose polymers stimulate the restoration of muscle glycogen.

The amount of carbohydrates, and basically the type of dietary fiber fraction (soluble/ insoluble, digestible/ indigestible, fermenting/non-fermenting) depends on the type of work. Certainly, an important issue in the nutrition of sporting dogs is the reduction of indigestible carbohydrates (up to $5 \%$ crude fiber in dry matter) due to the risk of osmotic diarrhea, as well as the adverse effect of the increased amount of gases formed during fermenting fiber and fecal matter, which is additional ballast during the run. In addition, increased dietary fiber content raises fecal mass and reduces the availability of nutrients (especially those contributing to the viscosity of digestive tract content) (Fahey 1990; Hill1998).

\section{SUMMARY}

Working dog nutrition is a big challenge for their owners. Each sporting dog (and its type of activity) should be treated individually. The correct diet of a sporting dog, with a balanced content of basic nutrients in the right proportions, is one of the key factors affecting the dog's sports results. The best indicator of the proper nutrition of such a dog is to assess the physical form, condition of the skin and coat. A properly fed dog performs its tasks much better and has more energy, so it becomes more efficient. In addition to the right amount of the main nutrients in the diet and their mutual proportions, the proper supply of vitamins, minerals and supplements for which sporting dogs also have an increased demand is also extremely important. These aspects of sporting dog nutrition will be discussed in the next article on a presented subject.

\section{REFERENCES}

Adkins T.O., Kronfeld D.S. 1982. Diet of racing sled dogs affects erythrocyte depression by stress. Can. Vet. J. 23, 260-263.

Barrette D. 1989. Feeding the sporting dog. Can. Vet. J. 30, 440-441.

Biel W., Kowalewska-Łuczak I., Bośko P., Łysoń E. 2017. Podstawy żywienia psów pracujących, w: Szkolenie i użytkowanie psów. Trzecie Warsztaty Kynologiczne, Szczecin, 6-7 października 2017, [b.w.], 8-11. ISBN 978-83-7663-243-8. [in Polish] 
Brown W.Y., Vanselow B.A., Redman A.J., Pluske J.R. 2009. An experimental meat-free diet maintained haematological characteristics in sprint-racing sled dogs. Br. J. Nutr. 102, 1318-1323.

Case L.P. 2014. Dog food logic. Making smart decisions for your dog in an age of too many choices. Dogwise Publishing, Wenatchee, Washington, USA.

Diez M., Hornick J.L., Baldwin P., Van Eenaeme C., Istasse L. 1998. The influence of sugar-beet fibre, guar gum and inulin on nutrient digestibility, water consumption and plasma metabolites in healthy Beagle dogs. Res. Vet. Sci. 64(2), 91-96.

Donadelli R.A., Aldrich C.G., Jones C.K., Beyer R.S. 2019. The amino acid composition and protein quality of various egg, poultry meal by-products, and vegetable proteins used in the production of dog and cat diets. Poultr. Sci. 98(3), 1371-1378.

Drake A.G, Klingenberg C.P. 2010. Large-scale diversification of skull shape in domestic dogs. Disparity and modularity. Am. Nat. 175(3), 289-301.

Fahey G. 1990. Dietary fibre for dogs. I. Effects of graded levels of dietary beet pulp on nutrient intake, digestibility, metabolisable energy and digesta mean retention time. J. Anim. Sci. 68, 4221-4228.

FEDIAF. 2019. Nutritional guidelines for complete and complementary pet food for cats and dogs. The European Pet Food Industry, Bruxelles.

Fernandes J.G., Olsson I.A.S., Vieira de Castro A.C. 2017. Do aversive-based training methods actually compromise dog welfare? A literature review. App. Anim. Beh. Sci. 196, 1-12.

Gamble L.J., Frye C.W., Hansen C.M., Locasale J.W., Liu X., Davis M.S., Wakshlag J.J. 2018. Serum metabolomics of Alaskan sled dogs during endurance racing. Comp. Exercise Physiol. 14(3), 149-159.

Głogowski R., Hołda K. 2017. Suplementacja diety (psów i kotów) kwasem dokozaheksaenowym (DHA)-korzyści, zagrożenia, efektywność [Dietary supplements (dogs and cats) with docosahexaenoic acid (DHA)-benefits, risks, effectiveness]. Wet. Prakt. 14, 11-12. [in Polish]

Harris R.C., Lowe J.A., Warnes K., Orme C.E. 1997. The concentration of creatine in meat, offal and commercial dog food. Res. Vet. Sci. 62(1), 58-62.

Helman E.E., Huff-Lonergan E., Davenport G.M., Lonergan S.M. 2003. Effect of dietary protein on calpastatin in canine skeletal muscle. J. Anim. Sci. 81, 2199-2205.

Hill R.C. 1998. The nutritional requirements of exercising dogs. Nutr. Health 12(128), 2686-2690.

Hill R.C. 2004. Feeding dogs for agility, in: 8th Annual Dog Owners \& Breeders Symposium, University of Florida College of Veterinary Medicine 22-28, July 31, 2004, Courtesy of the AKC's Canine Health Foundation, [b.m.].

Hill R.C., Bloomberg M.S., Legrand-Defretin V., Burger D.H., Hillock S.M., Sundstrom D.A., Jones G.L. 2000. Maintenance energy requirements and the effects on diet on performance in racing greyhounds. Am. J. Vet. Res. 61, 1566-1573.

Hill R.C., Lewis D.D., Scott K.C., Omori M., Jackson M., Sundstrom D.A., Jones G.L., Speakman J.R., Doyle C.A., Butterwick R.F. 2001. Effect of increased dietary protein and decreased dietary carbohydrate on performance and body composition in racing Greyhounds. Am. J. Vet. Res. 62, 440-447.

Horoszewicz E., Iwaniuk M., Niedziółka R. 2018. Selected training systems for various types of working dogs. Folia Pomer. Univ. Technol. Stetin., Agric., Aliment., Pisc., Zootech. 345(48)4, 73-80.

Jahr T.H., Fergestad M.E., Brynildsrud O., Brun-Hansen H., Skancke E. 2019. Haematological and serum biochemical values in Norwegian sled dogs before and after competing in a $600 \mathrm{~km}$ race. Acta Vet. Scand. 61(1), 20-29.

Kim H.T., Deveenter G.M., Dinallo G.K., Frye C.W., Zanghi B.M., Wakshlag J.J. 2019. The effects of maltodextrin and protein supplementation on serum metabolites in exercising competitive weightpulling dogs. Comp. Exercise Physiol. 15(1), 25-33.

Kronfeld D.S., Ferrante P.L., Grandjean D. 1994. Optimal nutrition for athletic performance, with emphasis on fat adaptation in dogs and horses. J. Nutr. 124 (12), 2745-2753. 
Kronfeld D.S., Hammel E.P., Ramberg C.F. Jr., Dunlap H.L. Jr. 1977. Hematological and metabolic responses to training in racing sled dogs fed diets containing medium, low, or zero carbohydrate. Am. J. Clin. Nutr. 30, 419-430.

Loftus J., Yazwinski M., Milizio J., Wakshlag J. 2014. Energy requirements for racing endurance sled dogs. J. Nutr. Sci., 3, 1-5.

McKenzie E.C., Jose-Cunilleras E., Hinchcliff K.W., Holbrook T.C., Royer C., Payton M.E., Williamson K., Nelson S., Willard M.D., Davis M.S. 2007. Serum chemistry alterations in Alaskan sled dogs during five successive days of prolonged endurance exercise. J. Am. Vet. Med. Assoc. 230, 1486-1492.

Mirowski A. 2011. Żywienie psów sportowych. Cz. III. Białko, witaminy i składniki mineralne [Sporting dog nutrition. Part III. Protein, vitamins and minerals]. Mag. Wet. 9(20), 962-966. [in Polish]

Mirowski A. 2016. Ile tłuszczu w diecie psów zaprzęgowych? [How much fat in sled dogs diet?]. Mag. Wet. 10(25), 56-58. [in Polish]

Murray S.M., Patil A.R., Fahey Jr. G.C., Merchen N.R., Hughes D.M. 1997. Raw and rendered animal by-products as ingredients in dog diets. J. Anim. Sci. 75(9), 2497-2505.

Pratt-Phillips S.E., Olsen R., Geor R., Zirkle A., Moore A., Harkins C., Davis M. 2018. Effect of reduced protein intake on endurance performance and water turnover during low intensity long duration exercise in Alaskan sled dogs. Comp. Exercise Physiol. 14(1), 19-26.

Ramprasath V.R., Eyal I., Zchut S., Jones P. J. 2013. Enhanced increase of omega-3 index in healthy individuals with response to 4 -week n-3 fatty acid supplementation from krill oil versus fish oil. Lipids Health Dis. 12(1), 178-189.

Reynolds A.J., Carey D.P., Reinhart G.A., Swenson R.A., Kallfelz F.A. 1997. Effect of postexercise carbohydrate supplementation on muscle glycogen repletion in trained sled dogs. Am. J. Vet. Res. 58, 1252-1256.

Reynolds A.J., Fuhrer L., Dunlap H.L., Finke M.D., Kallfelz F.A. 1994. Lipid metabolite responses to diet and training in sled dogs. J. Nutr. 124(Suplement), 2754-2759.

Templeman J.R., Thornton E., Cargo-Froom C., Squires E.J., Swanson K.S., Shoveller A.K. 2020. Effects of incremental exercise and dietary tryptophan supplementation on the amino acid metabolism, serotonin status, stool quality, fecal metabolites, and body composition of mid-distance training sled dogs. J. Anim. Sci. 98(5), 1-12.

Toll P.W., Pieschl R.L., Hand M.S. 1992. The effect of dietary fat and carbohydrate on sprint performance in racing greyhound dogs, in: 8th International Racing Greyhound Symposium, Orlando, Florida January 11-12, 1992. [b.w.].

Turcsán B., Kubinyi E., Miklósi A. 2011. Trainability and boldness traits differ between dog breed clusters based on conventional breed categories and genetic relatedness. Appl. Anim. Behav. Sci. 132(1-2), 61-70.

Tvarijonaviciute A., Barranco T., Rubio M., Carrillo J.M., Martinez-Subiela S., Tecles F., Carrillo J.D., Ceron J.J. 2017. Measurement of creatine kinase and aspartate aminotransferase in saliva of dogs: a pilot study. BMC Vet. Res. 13(1),168, 1-6.

Wakshlag J., Shmalberg, J. 2014. Nutrition for working and service dogs. Vet. Clin. Small Anim. 44, 719-740.

\section{ŻYWIENIE PSÓW SPORTOWYCH CZĘŚĆ I. ZAPOTRZEBOWANIE NA ENERGIE, BIAŁKO, TŁUSZCZ I WĘGLOWODANY}

Streszczenie. Psy sportowe należą do dużej grupy psów, które wykonują określoną pracę dla człowieka. Rodzaj wykonywanej pracy można podzielić pod względem częstotliwości, intensywności i czasu jej trwania. Celem pracy była charakterystyka żywienia psów sportowych, 
skupiająca się na zapotrzebowaniu energetycznym oraz zapotrzebowaniu na składniki pokarmowe dostarczające energii (białko, tłuszcz i węglowodany). Prawidłowe żywienie jest jednym z najważniejszych czynników wpływających na wyniki sportowe osiągane przez psa. Celem prawidłowego żywienia trenujących psów jest dostarczenie im najwyższej jakości energii w odpowiedniej ilości. Równowaga pokarmowa zostaje osiągnięta, gdy dostarczane składniki pokarmowe umożliwiają organizmowi utrzymanie właściwego funkcjonowania wszystkich tkanek i gdy żaden ze składników nie występuje w nadmiarze lub niedoborze.

Słowa kluczowe: psy pracujące, dieta, zapotrzebowanie pokarmowe. 
